\title{
Laryngeal Cancer Clinical Regional Lymph Nodes TNM Finding v8
}

National Cancer Institute

\section{Source}

National Cancer Institute. Laryngeal Cancer Clinical Regional Lymph Nodes TNM Finding v8. NCI Thesaurus. Code C133128.

A clinical finding about one or more characteristics of laryng eal cancer, following the rules of the TNM AJCC v8 classification system as they pertain to staging of regional lymph nodes. 